\title{
Corporate Social Responsibility and the Role of Oil Companies in Community Development Projects in Rivers State Nigeria: An Evaluation.
}

\author{
Igbara, Felix N. ${ }^{1}$,Etu, Ndubuisi Okpara ${ }^{2,}$ Alobari, Collins M. ${ }^{3}$, Naenwi, \\ M-Epbari O. ${ }^{4}$ \\ 1,3\&4. (Department of Banking and Finance Rivers State Polytechnic,Bori, Nigeria) \\ ${ }^{2}$ (Department Sociology and Anthropology, University of Uyo, Uyo, Nigeria)
}

\begin{abstract}
Corporate Social Responsibility (CSR) has emerged as a strategy to initiate and bring about development for host communities through programmes and projects that is responsive to their needs. This paper evaluates CSR of oil companies and its role in community development projects in Rivers state, Nigeria. Data was collected using a four-point Likert type scale questionnaire administered on 230 respondents drawn from 10 oil producing communities selected through simple random sampling techniques. Simple percentage and mean scores were used to analyze data. The findings showed among others that for any developmental programmes and projects to be considered satisfactory in the study area, it has to take the prioritized needs of the host community into cognizance. The perceived needs of the host community differ significantly with that of the oil companies, and this could bring about dissatisfaction of CSR rendered by oil companies, hence lead to fail or abandoned project, more still, it could also generate restiveness which is a bane on community development in any locality. Therefore, identifying/meeting the perceived and prioritized needs of the host community by the oil companies, providing a feed-back mechanism that is capable of measuring the level of satisfaction of CSR by oil companies and engaging Rapid Rural Needs Assessment (RRNA) and Memorandum of Understanding (MoU) in any CSR programmes were some of the recommendations that could enhance CSR in the study area.
\end{abstract}

Keywords : Community, Corporate Social Responsibility, Development, Oil companies, Projects.

\section{INTRODUCTION}

Nigeria have been severally reported as the largest oil producer in Africa and the eight largest in the world, a fact which since the 1970s when oil was discovered has changed the country's political economy[1] [2 ] Oil have been seen in many instances as accurse as well as blessing, however, in which ever perspective it is viewed, the truth remains that it contributes about 90 percent of Nigeria's revenue. The importance of oil to the country's economy has made it the interest of everybody, those with positive and negative motives alike.

Rivers state is a major oil producing state in Nigeria and have seen its share of the conflicts that has bedeviled oil exploration in Nigeria since the oil boom. These conflicts have not gone unnoticed as it affects all the stakeholders in oil production, and being the backbone of the Nigerian economy, any conflict that disrupts its production directly affects the economy and therefore, affects the life of the citizenry. These have attracted the interest of the stakeholders and that of researchers to the cause of the conflicts which specifically is always between the host communities of the oil companies and the companies which the youths of these communities see as government allies [3 ][4 ]. These communities have accused the government together with the oil companies of exploring and exploiting natural resources in their environment, in the process of which they destroy their sources of livelihood. The process of oil exploration, leading to gas flaring, oil spillage, crop and aquatic environment destruction as a result of careless abandon which the oil companies have adopted as a method, is the major cause of agitation by the host communities of oil companies [5][6 ].

Therefore, to curb the restiveness which is becoming a part of life for the youths of these communities, the stakeholders have seen Corporate Social Responsibility (CSR) from the oil companies as one major method [7 ]. This is with believe that CSR programs and projects will go a long way in developing the communities where these oil companies live in to do business. Believing that these CSR programs and projects will tackle some developmental issues which these communities cry wolf for, the oil companies have been reported to have engaged in many CSR programs [8 ][ 9].

The extent to which these programs have solved the problem there were initiated to solve is an issue for evaluation. Therefore, in order to evaluate the extent of impact of CSR of oil companies on community development in their host communities, this paper have raised three objective questions as follows: why 
corporate social responsibility? How has oil companies fared in CSR projects in Rivers state? And to what extent have CSR projects by oil companies contributed in community development in the area?

\section{The Concept And Essence Of Csr}

According to [10 ], modern business managers are constantly exposed to the dilemma of matching contributions to the development of the environment within which they live in to operate from, and meeting the requirements of the small but powerful group, the shareholders. This is the dilemma of CSR in Rivers state who is the oil companies socially responsible to, the shareholders or the host communities? And who are they supposed to be responsible to? To answer the question, one need to take a look at the concept of Corporate Social Responsibility.

[11 ] states that the concept of CSR is relatively old in the business world spanning over seven decades; yet he said it has no generally accepted definition. But [12 ] argued that the nucleus of the concept hovers on an ongoing call on businesses not just to behave ethically but to equally contribute to the socio-economic development of the immediate society they live to carry on their business activities and the world at large while demonstrating respect for the people, the community and environment. Many definitions have been given for CSR, which [13 ] argued are often biased towards specific interests. Nevertheless, [14 ] who took a survey of CSR's definition reported the Commission of the European Communities' (CEC) definition as having the highest frequency count of 286. The commission's definition having been adopted as the working definition in this paper sees CSR as: "a concept whereby companies integrate social and environmental concerns in their business operations and in their interaction with their stakeholders on a voluntary basis".

A closer look at the above definition by the CEC, will reveal a stride towards answering the earlier question: who is the oil companies socially responsible to and who are they supposed to be responsible to? The definition sees an integration of social and environmental concerns in their business process, as well as in their interaction with the stakeholders. In other words, the companies in executing their CSR must not lose touch with the interest of the host communities even as they struggle to make profit for their shareholders. To further the answer on who the oil firms are supposed to be responsible to, and as well look at the essence of CSR, the paper looks at the two popular theories of CSR: the shareholders and the stakeholders theories.

\subsection{The Shareholder Theory:}

The work of Milton Friedman in [15 ] gave the theory its popularity, when it was asked: "so the question is do corporate executives, provided they stay within the law, have responsibilities in their business activities other than to make as much money for their shareholders as possible?" Friedman answered thus: "and my answer to this is, no, they do not". He emphasized that the businesses must operate within the law and be morally ethical - stance that complicates his assertion of no responsibility other than making profits. The question is, to what extent are the oil companies in the Niger Delta being morally ethical, when oil spillage have damaged the crops of host communities and destroyed aquatic life? How much are they operating within the law, when they have been severally accused to have sponsored the continuous stay in power of the military government which favours their unwholesome practices? [16 ].

\subsection{The Stakeholder Theory:}

This theory, though existing before, was brought to limelight by Freeman [17]. "Strategic Management: A Stakeholder Approach". This approach argues that businesses don't just exist to satisfy the shareholders' interest of maximizing profit. The point is that for a long run existence and profit making of the business, the stakeholders' interest has to be considered, and he identified the stakeholders as those who affects and are affected by the operations of the business. In this case, Freeman's argument is that the oil companies in order to do business in the Nigerian Niger Delta, generally, and Rivers State in particular, have to satisfy the stakeholder this in this case includes among others the host communities. This theory implies that when the stakeholders are satisfied, the shareholders will as well be satisfied in the long run, because evidently, the oil companies have not fared well in their operations in the face of militancy, agitation, protest, youth restiveness etc. in Rivers State.

Therefore, CSR is seen in this paper as serving double purpose. First, the companies have to cover the interest of the host communities. It is only when this is done that peace and security can be restored in their business environment for the smooth running of their business, which if not achieved, is the bane for continuous existence and profit making - the interest of shareholders.

\section{Methodology}

The question now is, how much have oil companies in Rivers state executed their CSR projects and to what extent does these projects reflect the developmental needs of the communities? In other words does the CSR projects executed, satisfactorily solve the problems they are meant to solve? To find out, this study, carried 
out in Rivers state Nigeria, used the purposive sampling method to select four oil companies in the state which include: Total E and P Nigeria limited (TEPN), Chevron/Texaco, Nigeria Agip Oil company (NAOC), and Shell Petroleum Development Company (SPDC). Then using the table of random numbers, ten oil producing communities were selected and fifteen questionnaires distributed in each community to get a total of 150 respondents from the communities. 20 questionnaires were distributed in each of the four selected oil companies, to get a total of 80 respondents from the oil companies.

Therefore, using a multi-stage sampling technique, a total of 230 respondents were selected to form the sample size for the study. Simple percentage and mean scores developed from four-point Likert type scale of 'highly satisfied', 'satisfied', 'dissatisfied', 'highly dissatisfied', were used to analyze data collected. The purpose of the questionnaire was to ascertain the extent to which the host communities are satisfied with the CSR projects in their communities.

\subsection{Developmental needs host communities:}

\section{Findings And Discussion Of Results}

Factors that determine development were in this study identified as the following: infrastructure, health, agriculture, security, education, and job/empowerment. Then asked on their developmental needs in order of importance, the respondents' response according to data in Table 1 are as follows:

Table1. Developmental needs of communities in Rivers state.

\begin{tabular}{|c|c|c|c|c|c|c|c|c|c|c|c|c|c|}
\hline \multirow[b]{2}{*}{ Needs } & \multicolumn{10}{|c|}{ Communities } & \multirow[b]{2}{*}{ 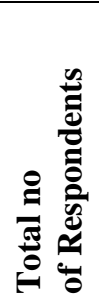 } & \multirow[b]{2}{*}{ 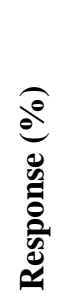 } & \multirow[b]{2}{*}{ 先 } \\
\hline & 름 & $\begin{array}{l}\frac{\vec{z}}{0} \\
\text { ğ }\end{array}$ & $\begin{array}{l}\Xi \\
0 \\
0 \\
0 \\
0 \\
0\end{array}$ & $\begin{array}{l}\stackrel{0}{\overline{0}} \\
\stackrel{0}{60} \\
0\end{array}$ & $\frac{\pi}{\Xi}$ & 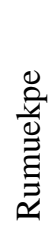 & $\begin{array}{l}\overline{000} \\
\text { }\end{array}$ & 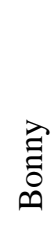 & $\begin{array}{l}0 \\
\text { Dे } \\
0\end{array}$ & 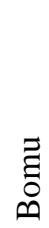 & & & \\
\hline Education & 14 & 14 & 12 & 13 & 11 & 14 & 13 & 13 & 10 & 14 & 128 & 85 & $1^{\mathrm{st}}$ \\
\hline Job/Empowerment & 14 & 10 & 13 & 11 & 14 & 9 & 10 & 10 & 11 & 9 & 111 & 74 & $2^{\text {nd }}$ \\
\hline Infrastructure & 10 & 14 & 8 & 9 & 10 & 14 & 12 & 7 & 8 & 7 & 99 & 66 & $3^{\text {rd }}$ \\
\hline Health & 9 & 12 & 5 & 6 & 13 & 12 & 10 & 12 & 11 & 5 & 95 & 63 & $4^{\text {th }}$ \\
\hline Agriculture & 14 & 12 & 5 & 10 & 10 & 6 & 5 & 5 & 5 & 6 & 78 & 52 & $5^{\text {th }}$ \\
\hline Security & 10 & 11 & 5 & 7 & 8 & 5 & 5 & 6 & 7 & 5 & 69 & 46 & $6^{\text {th }}$ \\
\hline
\end{tabular}

Source: Field survey 2013

Table 1 shows the perceived needs of communities in Rivers state as indicated by the oil bearing communities studied. It reveals that education is the most needed in this communities as a total number of 128 $(85 \%)$ of the respondents responded in favour of that. The next in rank is Job/Empowerment which scored $74 \%$, followed by Infrastructure with $66 \%$. health ranked $4^{\text {th }}$ with $63 \%$, while Agriculture and security scored 52 and $46 \%$ to rank $5^{\text {th }}$ and $6^{\text {th }}$ respectively. The finding shows that for any developmental program to be considered satisfactory in these communities, it has to take these needs into consideration, in its order of importance. Also, findings according to their perceived needs indicates that security was not challenge, though ranked the least in the list of needs. Therefore, security challenges within the study area is a product of constant agitations, youth restiveness, protest which in most cases has been hijacked by ill motived individual, hence, threatens the security of the area. Thus, concentrated efforts to address the above needs through Corporate Social responsibility-CSR (by oil producing companies) will not only address community development challenges in the area, but will also arrest the problem of insecurity in the area.

\subsection{CSR programmes in host communities:}

This analysis is made to ascertain which of the above needs have been covered by the CSR programs of the oil companies, to what extent and by which company.

Table 2. CSR programs in host communities.

\begin{tabular}{|c|c|c|c|c|c|c|}
\hline \multirow{2}{*}{ CSR programs } & \multicolumn{4}{|c|}{ Companies } & \multirow{2}{*}{$\begin{array}{c}\text { Total No } \\
\text { of } \\
\text { Respondents }\end{array}$} & $\begin{array}{c}\text { Response } \\
(\%)\end{array}$ \\
\cline { 2 - 7 } & Total E \& P & Shell & NAOC & Chev./Texaco & 72 & 90 \\
\hline Education & 18 & 18 & 17 & 19 & 65 & 81 \\
\hline Health & 16 & 18 & 17 & 14 & 64 & 80 \\
\hline Infrastructure & 19 & 17 & 14 & 14 & 45 & 56 \\
\hline Agriculture & 10 & 11 & 12 & 12 & & \\
\hline
\end{tabular}


Corporate Social Responsibility And The Role Of Oil Companies In Community Development

\begin{tabular}{|c|c|c|c|c|c|c|}
\hline $\begin{array}{c}\text { Employment/Skill } \\
\text { Acquisition }\end{array}$ & 15 & 16 & 18 & 11 & 59 & \\
\hline Security & 7 & 13 & 16 & 12 & 60 \\
\hline Charity & 8 & 7 & 10 & 6 & 38 & 39 \\
\hline Sport promotion & 11 & 15 & 5 & 5 & 36 & 23 \\
\hline $\begin{array}{c}\text { Tourism } \\
\text { promotion }\end{array}$ & 5 & 5 & 7 & 6 & 29 \\
\hline
\end{tabular}

\section{Source: field survey 2013}

Data in Table 2 reveals, as indicated by the oil companies, that the CSR programs undertaken by these companies in their host communities are as follows: education with the highest response of $90 \%$, followed by Health with $81 \%$ response, then Infrastructure with $80 \%$ response. Employment/Skill Acquisition comes next with 74\%, security got 60\% response and Agriculture with 56\%. Below 50\% responses are Sports promotion, Charity and Tourism promotion with 45,39 , and $29 \%$ respectively.

From the above, it could be inferred that the oil companies have been able to identify the developmental needs of the host communities as: education, health, infrastructure, Employment/Skill Acquisition, security and agriculture, including sports, charity and tourism. But it could also be deduced from the percentage response that the order of importance have been altered. While the communities ranking of their needs in order of importance from top down are: education, Employment/Skill Acquisition, infrastructure, security, agriculture, and health; the oil companies' percentage response to CSR programs from top down are as follows: education, health, infrastructure, job, security, and agriculture. This therefore shows that there are discrepancies on the community perceived needs in ranking, and that of the oil companies. These discrepancies may not be an issue of concern for the oil companies or neglect in the side of the host communities. however, the level of satisfaction of the host communities with the corporate social responsibility of oil companies measured interms of access and utilization of the perceived ranked needs in table 1 and 2 will solve and justify the research objectives. Hence, the need to measure the level of satisfaction of host communities with the CSR programs of oil companies. This is the main preoccupation of the next section.

\subsection{Perceived level of satisfaction of host communities with the CSR of oil companies:}

Data in Table 3 represents the level of satisfaction of host communities with the CSR programmes and projects of oil companies in the study area.

Table 3 the level of satisfaction of host communities with the CSR programs.

\begin{tabular}{|c|c|c|c|c|c|c|c|c|c|c|c|}
\hline \multirow[b]{2}{*}{ 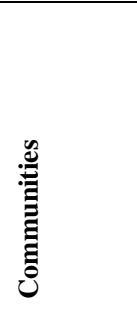 } & \multirow[b]{2}{*}{ 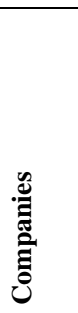 } & \multicolumn{9}{|c|}{$\begin{array}{l}\text { Corporate Social Responsibility } \\
\end{array}$} & \multirow{2}{*}{ Mean * } \\
\hline & & 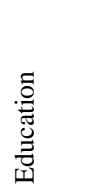 & 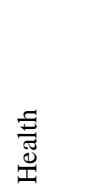 & $\stackrel{8}{\circ}$ & 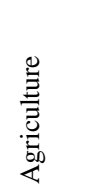 & 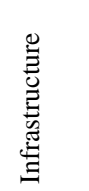 & $\begin{array}{l}\vec{E} \\
\text { 苞 }\end{array}$ & $\begin{array}{l}\text { 言 } \\
\text { 品 }\end{array}$ & $\begin{array}{l}\text { 总 } \\
\text { के }\end{array}$ & $\begin{array}{l}\text { 离 } \\
\text { 言 } \\
\end{array}$ & \\
\hline Bonny & \multirow{3}{*}{$\overline{\bar{v}}$} & $4(1.6)$ & $8(3.2)$ & $6(2.4)$ & $3(1.2)$ & $7(2.8)$ & _- & $2(0.8)$ & _- & $1(0.4)$ & (1.4) \\
\hline Bodo & & $8(3.2)$ & $5(2.0)$ & $3(1.2)$ & $8(3.2)$ & $9(3.6)$ & $4(1.6)$ & $5(2.0)$ & $3(1.2)$ & $5(2.0)$ & $(2.2)$ \\
\hline Bomu & & $6(2.4)$ & $7(2.8)$ & $8(3.2)$ & - & $2(0.8)$ & $3(1.2)$ & $5(2.0)$ & $1(0.4)$ & - & (1.4) \\
\hline Egi & \multirow[b]{2}{*}{$\begin{array}{l}]_{0}^{2} \\
0 \\
0\end{array}$} & $3(1.2)$ & $7(2.8)$ & $4(1.6)$ & $8(3.2)$ & $9(3.6)$ & $4(1.6)$ & $3(1.2)$ & $3(1.2)$ & $4(1.6)$ & $(2.0)$ \\
\hline Rumuekpe & & $7(2.8)$ & $6(2.4)$ & $4(1.6)$ & - & $5(2.0)$ & - & $4(1.6)$ & - & $1(0.4)$ & $(1.2)$ \\
\hline Idu & \multirow[b]{3}{*}{ 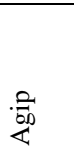 } & - & $6(2.4)$ & $9(3.6)$ & _- & $4(1.6)$ & $5(2.0)$ & $8(3.2)$ & $3(1.2)$ & _- & $(1.5)$ \\
\hline Omoku & & $7(2.8)$ & $9(3.6)$ & $4(1.6)$ & $3(1.2)$ & $5(2.0)$ & $1(0.4)$ & $9(3.6)$ & $2(0.8)$ & $5(2.0)$ & $(2.0)$ \\
\hline Obirikom & & $8(3.2)$ & $6(2.4)$ & $5(2.0)$ & $8(3.2)$ & $8(3.2)$ & $4(1.6)$ & $5(2.0)$ & $5(2.0)$ & $3(1.2)$ & (2.3) \\
\hline Ogbelle & \multirow{2}{*}{ 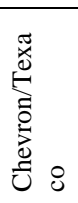 } & $5(2.0)$ & $7(2.8)$ & - & $4(1.6)$ & $6(2.4)$ & - & $4(1.6)$ & - & $2(0.8)$ & $(1.2)$ \\
\hline Kula & & $4(1.6)$ & $8(3.2)$ & $7(2.8)$ & $5(2.0)$ & $8(3.2)$ & - & $5(2.0)$ & - & $3(1.2)$ & (1.7) \\
\hline
\end{tabular}

Source: field survey 2013

$*$ Maximum mean score $=4 ; 2.0$ and above $=$ satisfied; below 2.0 $=$ dissatisfied .

Data in Table 3 reveals the level of satisfaction of host communities with the CSR programs undertaken by oil companies in their communities. It shows that 4 out of the 10 communities sampled in this 
study express satisfaction with the CSR projects in their communities. The four are Bodo with mean value 2.2, Egi with 2.0, Omoku with 2.0 and Obirikom with 2.3. The remaining six communities express dissatisfactions with mean values between 1.2 and 1.7. Therefore, majority of the oil producing communities are not of the opinion that the CSR projects by oil companies have done enough towards the development of the host communities. Hence, the result confirmations the discrepancies in their perceived areas of developmental needs between the host communities and oil companies as shown in Table 1 and 2.

This finding reveals a major challenge in community development drive which various studies [ 17 ][18 ][ 19 ] have implicated consent as a bane community development programmes and projects in various locations in the Nigeria context. Thus, brings about failed and unsuccessful projects or programmes. It is therefore imperative to introduce Rapid Rural Needs Assessment (RRNA) and/or Memorandum of Understanding (MoU) for a successful CSR programmes and projects which are encourages community participation, and of course, are best practices in recent times.

\section{CONCLUSIONAND RECOMMENDATIONS}

Solutions have been sought from many angles to arrest the issue of youth restiveness, which gave birth to the concept of Corporate Social Responsibility (CSR). But how much these CSR programs have tackled the developmental needs of the host communities of oil Companies, is an issue of discussion. This paper found that the developmental needs of the communities in River state include education, health, infrastructure, security, agriculture, and job/empowerment, but the oil companies with the full knowledge of this fact have misplaced priority among these needs which affects the effective execution of CSR programs, and therefore hinder community development programmes and projects in the study area.

The paper therefore, in the bid to contribute to the solution for youth restiveness through community development, recommends as follows: The oil companies need to take a second look at the order of importance of the needs of host communities. Education has been identified by these communities as their most pressing need and therefore must be treated as such. [21] have seen education as sin qua non for personal and societal development. Therefore, if the oil companies tackle the education of their host communities, it is believed that other things will fall in place. Give the education system a good standard to compete with the international system, else how do you give a job to a child trained in an ill equipped school and expect him to compete favorably with the one trained in a well-equipped school?

Nevertheless, identifying these needs by priority is not enough until it is able to solve the problem of youth restiveness through community development. Constraints to the execution of CSR programs have been identified to include youth restiveness, poor company budgeting, traditional beliefs etc.[22][23]. Youth restiveness can be solved if the needs of the youths are meet. Give them education, good health, means of livelihood which is not just job but empowerment such as skill acquisition and conducive environment for business, through security.

Moreover, the shareholder theory is still surfacing in the operations of the oil companies, which is why poor company budget have been identified as a constraint to the execution of CSR projects. The oil companies are advised therefore, to follow the Stakeholders theory's tenets which states that if the stakeholders are satisfied, the business thrives to satisfy the shareholders in the long run. Therefore, let the budget of the oil companies include the prioritized needs of the host communities, and executed as part of the business process. Finally, the execution of the CSR programs should be done in partnership between the host communities and the oil companies to ensure monitoring and evaluation and transparency. The terms of this partnership should be defined the Memorandum of Understanding (MoU) instituting the CSR program, and must be followed to the later.

\section{Acknowledgements}

The authors are grateful to Mr. Lawrence Udensi of Youth Empowerment and Child Labour Elimination Project (YCEP) Calabar, Cross River State, Nigeria;for his useful suggestions on data collection method, and for painstakingly going through the manuscript for both typographical and technical editing.

\section{REFERENCES}

[1] N.C. Alagoa, Partnering for community development - stakeholder comment, (SPDC, People and Environment, Portharcourt, 2003).

[2] I.N. Odua, Comparative analysis of community development programs of Nigeria Agip Oil Company and Totalfina Elf Nig. Ltd in Ogba/Egbema/Ndoni local government area of Rivers state, M.Sc. thesis, department of agricultural economics and extension, Rivers state university of science and technology. Portharcourt, 2007.

[3] I. Ezinwo, Kula Community Protest. Independent Monitor, December 13-14, 10 (98), 2004, 3

[4] O. Ayo, Corporate social responsibility as a success in organizations, in readings of public relations 3,(Abeokuta, NIPR, 2002) 1525.

[5] R.G. Nwobigwe, The socio-economic impact of oil exploration on Ogba/Egbema/Ndoni local government area of Rivers state, B.Sc. project, Rivers state university of science and technology. Portharcourt. 1998. 
[6] I. Ezinwo, Kula Community Protest. Independent Monitor, December 13-14, 10 (98), $2004,3$.

[7] N.C. Alagoa, Partnering for community development - stakeholder comment, (SPDC, People and Environment, Portharcourt, 2003).

[8] P. Mzurkiewicz, Corporate environmental responsibility: is a common CSR framework possible? A discussion Paper, DevComm, Worldbank. 2005.

[9] O. I. Natufe, The problematic of sustainable development and corporate social responsibility: Policy Implication for the Niger Delta, Being a paper presented on the second annual CONFERENCE and general meeting of the Rockaway, river country club Denville, New Jersey, USA, 2001

[10] S.P. Singh, Strategic management, (New Delhi: AITBS Publishers, 2006).

[11] J. Gustafson, Corporate social responsibility: Are you giving back or just giving away? Business the ultimate resource (Winchester U.k.: Bloomsbury Publishing Plc, 2002)

[12] C.W. Soreh, 2012) Corporate social responsibility and youth restiveness in oil rich niger delta region of Nigeria, Arabian Journal of Business and Management Review, 1(7), 2012,58.

[13] D.J. Olawari, and A.E. Fidelis, The rhetoric of corporate social responsibility (CSR) in the Niger Delta, American International journal of Contemporary Research, 1(3), 2011.

[14] A. Dahlsrud, How corporate social responsibility is defined: An analysis of 37 definitions, Wiley Interscience, (2006). Available online at: www.interscience.wiley.com. Retrieved $3^{\text {rd }}$ October, 2013.

[15] M. Friedman, The social responsibility of business is to increase profit, (The New York Times Magazine, New York 1970).

[16] M. Bronwen, Shell in Nigeria: Corporate Social Responsibility and the Ogoni Crisis. A Case study for The Carnegie Council on Ethics and International Affairs, 1995, available online at: www.cceia.org. Retrieved $3^{\text {rd }}$ October, 2013.

[17] R.E. Freeman, Strategic management: A stakeholder approach,(Prentice-Hall Englewood CliffsNew Jersey, 1984).

[18] A. B. Bassey, L.O. Udensi, L.K. Daasi Gibson, F.N. Igbara, Engaging MOU and people's participation in project implementation: Imperative for sustainable community development in Nigeria, Research on Humanities and Social Science, 3 (2), $2013,27-3$.

[19] L.O. Udensi, O.S. Udoh, L.K. Daasi Gibson, F. N. Igbara, (2012). Community leadership and the challenges of community development in Nigeria: The case of Boki local government area, Cross River State. International Journal of Development and Sustainability, I (3), 2012, 1-12.

[20] L.O. Udensi, L.K. Daasi Gibson, D.S. Emah, S. A. Zukbee, Youth participation in community development (CD) programmes in Cross River state: Implication for sustainable youth development in Nigeria. ISOR Journal of Humanities and Social Sciences, 13 (4), 2013, 55-61

[21] UNESCO, Net enrollment rate in primary education, Education for all monitoring report, 2008

[22] B.I. Isife, C.O. Albert, N. Chukuigwe, Community restiveness and corporate social responsibility of oil companies in Rivers state, Southern Nigeria, Global Advanced Research Journal of Agricultural Science, 1(10), 2012, 309-313.

[23] A.B. Gabriel-Pidomson, Causes and effects of conflict in Ogonikingdom of Rivers state. M.Sc. thesis, Department of Agricultural Economics and Extension, Rivers state University of Science and technology, Portharcourt, 2008. 